\title{
Medieval and Renaissance Philosophers on Education
}

\author{
Tetiana Danylova ${ }^{1}$, Ihor Hoian ${ }^{2}$ \\ ${ }^{1}$ National University of Life and Environmental Sciences of Ukraine \\ 15 Heroiv Oborony street., Kyiv, 03041, Ukraine \\ 2 Vasyl Stefanyk Precarpathian National University \\ 57 Shevchenko str., Ivano-Frankivsk, Ukraine, 76018
}

DOI: $10.22178 /$ pos.63-8

LCC Subject Category: BF38-64

Received 25.09.2020

Accepted 26.10.2020

Published online 31.10.2020

Corresponding Author:

dtv280365@gmail.com

(c) 2020 The Authors. This article is

licensed under a Creative Commons

Attribution 4.0 License @ (1)
Abstract. Philosophical understanding of education is a logical continuation of philosophical interpretation of the world and human beings in it. Therefore, it is not surprising that such an important social sphere has attracted the attention of philosophers for centuries. Even a cursory glance at their concepts reveals that they have touched upon most issues that are still relevant today. The paper attempts to briefly describe the educational ideas of Titus Flavius Clemens, Origen, Saint Augustine, Boethius, Thomas Aquinas, Francesco Petrarch, Vittorino de Feltre, Michel de Montaigne, Erasmus of Rotterdam, Thomas More, Tommaso Campanella. The authors used hermeneutical, cultural-historical, and integrative approaches.

Keywords: education; philosophy; the Middle Ages; the Renaissance; humanism.

\section{INTRODUCTION}

The great interest of philosophers in the problems of education is determined by the very fate of philosophy, its past, and future. Philosophical understanding of education is a logical continuation of philosophical interpretation of the world and human beings in it. "Every epoch, every society, every culture has uniquely interpreted the concept and essence of education. This largely depends on the mentality of a society that influences the educative doctrine and also undergoes dramatic changes. The philosophy and psychology of education is the center, the battlefield of worldviews and system of values" [6]. Therefore, it is not surprising that such an important social sphere has attracted the attention of philosophers for centuries. Even a cursory glance at their concepts reveals that they have touched upon most issues that are still relevant today.

\section{RESULTS AND DISCUSSION}

The concept of the "Middle Ages", which was first used by humanists in the second half of the 15th century, has become widespread and is actively used in the historiography of world history. This is the name of the longest period of the historical development of Western Europe - from the fall of the Roman Empire in the 5th century till the beginning of the Renaissance (14-15th centuries). During this period, the slave-owning society was replaced by a way of life associated with the emergence of feudal relations, the stronghold of which was Christianity.

The replacement of the oral culture with written, which made it easier to transfer knowledge, was a striking feature of this period. The cult of the Word was asserted. The text became very important. To achieve the goal of understanding God, which was set by medieval sages, it was necessary to read and interpret the Bible the whole life. Medieval thinkers interpreted sacred texts and preached on their basis - hence a new understanding of life as eternal discipleship. Individuals felt themselves a part of the whole, that is, God, and saw the meaning of their lives in the attachment to the Divine Blessing. Every Christian is first and foremost a disciple of God. There- 
fore, most theologians were either preachers or teachers.

The emergence and development of the medieval era education were associated with the development of the church culture, which used it both to preach religious dogma and to combat heretics. For the first time, the question of the need to develop a program of the church education to implement the ideas of Christianity was raised by Aurelius Augustine, who opposed the use of pagan elements in Christian education. At the beginning of the 7th century, the first church schools appeared in Ireland and Britain due to the activity of the monks. The opening of the schools at the monasteries was facilitated by the fact that the ancient manuscripts that could serve as textbooks were preserved there. There were several levels of education in medieval schools. At the elementary level, children learned to read, write, count, sing. Latin, rhetoric, dialectics were studied at the intermediate level, and finally, at the highest level, arithmetic, geometry, astronomy, and music were added to these subjects.

A medieval man perceived the world as one big school, in which Jesus Christ was the supreme teacher and whose sermons were divine lessons. If the ideal of the Ancient times was a citizen, a warrior, a man who reached his heyday, in Christian Europe, it was believed that people should become like children. As far as the world is a school, it is not society that forms the school, but the school forms the world and culture. If in early Christianity love was considered higher than knowledge and faith, then later Christian authors emphasized the ideas of authority and teaching, unconditional adherence to discipline. All questions and answers were known in advance, the student only needed to repeat the teacher's explanation.

A Christian theologian and philosopher Titus Flavius Clemens (also known as Clement of Alexandria), noted that in addition to external education a person should have a religious feeling [3]. The purpose of education is to teach a child the Christian way of life, "improve" a child's soul. The task of a teacher is to lead the youth on the path of good and lay the foundations for comprehending the truth in the process of active dialogue. The example of a teacher's life is a role model for students. A Christian scholar and theologian Origen of Alexandria believed that a man was a combination of a soul and a body, and this unique com- bination provides opportunities for selfimprovement [10].

According to one of the most famous Christian theologians and philosophers of the Patristic period of church history Augustine of Hippo (also known as Saint Augustine), the purpose of education is to merge with God. In his treatise "The City of God" [14], he attempted to combine ancient philosophy and the ideas of Christianity into a single doctrine of good and evil, human sinfulness, love, salvation, and repentance. The basis of knowledge for the philosopher was a synthesis of feelings, thoughts, and pious aspirations. He considered self-immersion, self-analysis to be the most important method of cognition because the soul hid the truth and only the cognition of this truth paved the way to God.

The so-called last Roman philosopher Anicius Manlius Severinus Boethius developed the foundations of the scholastic method and gave the Latin equivalents to the categories of Greek philosophy. According to the thinker, the study of the seven liberal arts, especially quadrivium (geometry, arithmetic, astronomy, music) makes the mind sharp, promotes logical thinking, and, most importantly, understanding of the philosophical sciences, full and comprehensive knowledge of the divine wisdom is impossible without it. The disciplines of the quadrivium are the steps to higher knowledge, that is, to philosophy which is truth [1]. Thus, it was Boethius who laid the foundations of the characteristic features of medieval education, i.e., its contemplation and detachment from the practical needs.

In the 11-13th centuries under the conditions of profound changes in the political and spiritual life of society, a new type of religious philosophy - scholasticism - emerged. It was "the philosophical systems and speculative tendencies of various medieval Christian thinkers, who, working against a background of fixed religious dogma, sought to solve anew general philosophical problems (as of faith and reason, will and intellect, realism and nominalism, and the probability of the existence of God), initially under the influence of the mystical and intuitional tradition of patristic philosophy, especially Augustinianism, and later under that of Aristotle" [13]. Scholasticism contributed to the formation of a certain type of culture focused on the formal logic of Aristotle and abstract theology. The most important role was played by the most authoritative Catholic religious philosopher and theologian the Doctor 
of the Church Thomas Aquinas. In a kind of encyclopedia of Catholic theology "Summa Theologiae" [15] he reinterpreted church knowledge, tried to subordinate secular knowledge to faithbased on the ethics, logic, and psychology of Aristotle. His activities were aimed at giving faith a form of scientific knowledge. For several centuries, the works of Thomas Aquinas served as the main source for the study of theology in European schools of advanced type - colleges and universities.

The separation of crafts from agriculture and the emergence of cities was of great importance for the development of medieval education. The emergence of early urban culture was a significant moment in the history of society because it broke the centuries-old monopoly of the Catholic Church in the field of intellectual education. Advocates of secular culture grouped around urban schools that were separated from the church. These schools differed from the church in both program and contingent. Secular urban schools were a fundamentally new phenomenon in the intellectual life of medieval society. The secular school was private and existed at the expense of the fees charged to students. Many schools of this type arose in northern France, which became one of the centers of intellectual education at the beginning of the 12th century. These schools were headed by people who asserted the priority of reason, bowed to ancient philosophy, and glorified secular knowledge.

The cultural dominance of the Middle Ages, which determined the direction of education and pedagogical thought, was a human desire for a perfect world, serious religious and moral attitude to inner life, physical and spiritual asceticism. The earthly world seemed perishable and sinful, it was not the subject of study and change. Scholarship and education were intellectual, bookish, detached from life. The reaction to such a one-sided worldview and self-determination were deep processes in cultural development, which were manifested in the ideology of the Renaissance and the Reformation in the 14-16th centuries.

The Renaissance is a transitional period from the Middle Ages to the New Age, which covers several centuries (Italy - 14-16th centuries, other European countries - 15-16th centuries) when the Middle Ages in its economic, social, political, spiritual forms had already exhausted itself and the new bourgeois system has not yet been estab- lished. At this time, significant changes were observed in the spiritual life of society. Urban secular culture became widespread, and its representatives rethought the traditionally religious, ethical, and aesthetic views of the Middle Ages without breaking with them completely. Interest in the ancient heritage was revived, it was seen as a source of new ideas. There was a new type of worldview, at the center of which was an active person who can change the world [4]. Asceticism with its denial of the joys of earthly life, the desire to prepare for eternal life was opposed by the ideal of a comprehensively developed, strong in spirit and body man who sought selfdetermination and self-realization in this world and not in the afterlife.

The diverse needs, wishes, motives of a human personality were manifested in humanism. The concept of humanism in the broadest sense of the word is a system of ideas and views on a human as the highest value, in a narrower - is a progressive trend of the Western European culture of the Renaissance aimed at respect for human dignity and reason, his/her right to earthly happiness and the free manifestation of natural human feelings and abilities. The bearers of the new worldview were people of different social strata, primarily citizens who studied philosophy, as well as poets and artists. The object of their study was a human being. Humanists understood that the new ideals could be affirmed through the education and upbringing of the new generations. Putting a man at the center of their worldview, humanists associated the moral and social progress of society with purposeful education. This explained the special attention to pedagogy during the Renaissance. A new goal of education was formulated and the factors that contributed to the development of a harmonious personality were studied in the pedagogical works of the most prominent humanists. Particular emphasis was placed on the intellectual, moral, and aesthetic elements of education.

The Italian poet and humanist Francesco Petrarch [11] believed that a man has the right to be happy in the real, earthly life. He defended the dignity of a man, the uniqueness of his/her inner world with hopes, experiences, and anxieties. To achieve complete independence, self-control, and peace of mind is possible under the conditions of a person's internal struggle with his/her passions and confrontation with the surrounding world. 
The Italian humanist and educator Vittorino de Feltre saw the purpose of education in the formation of a harmoniously developed human. He established the secondary school "The House of Joy" in Mantua: "the spacious school contained broad corridors and well-lighted and lofty rooms and was surrounded by broad meadows, walks, and trees... Vittorino believed that learning proceeded more efficiently in pleasant surroundings and sought to create and maintain a physically attractive school" [7]. The education was based on Latin and Greek, ancient literature, logic, rhetoric, arithmetic, geometry, algebra, science, music. Much attention was paid to moral education based on Christian ethics. Classical education at school was supplemented by physical education. Vittorino de Feltre abandoned scholastic disputes, corporal punishment, and in the process of teaching, he used elements of the game. The thinker considered self-education a necessary component of human development.

The French philosopher and writer of the Renaissance era Michel de Montaigne in his "Essays" [8] proposed the concept of a new type of a man who was highly educated and able to think critically. He considered the natural inclinations of a child to be the main reference point of the educator's activity. According to the philosopher, the experience should be the basis of knowledge. Montaigne saw a significant shortcoming of the educational process in the fact that students were offered ready-made truths, which they accepted uncritically. To prevent this, people need to be taught to observe, compare, contrast, draw their conclusions. Therefore, the most valuable knowledge is knowledge obtained as a result of personal experience. Montaigne's educational ideas were later developed by the representatives of the Enlightenment.

Erasmus of Rotterdam - the famous humanist, writer, philologist, theologian - was one of the first to put forward the idea of public education. Determining the content of education, he put grammar at the forefront; it was followed by history and literature, geography, and science. Erasmus of Rotterdam opposed strict school discipline, severe punishment, and emphasized that the educational process should bring joy and satisfaction to the students. The purpose of education, in his opinion, is to develop a sense of moral duty [12].

The English thinker Thomas More argued for the possibility of providing "spiritual freedom and education" for all citizens. In his book "On the Best Form of a Commonwealth and on the New Island of Utopia: A Truly Precious Book No Less Profitable than Delightful" [9], the thinker depicted a fair social system (in his opinion) where people work and the state cares about education and upbringing. T. Moore expressed the need for universal, equal for all people education in the native language; put forward the principle of clarity and observation of nature; emphasized the harmonious development of personality and the need to form such virtues as modesty, hard work, and kindness.

The social character of education was emphasized by the Italian philosopher and writer Tommaso Campanella. In his work "The City of the Sun" [2] he portrayed an ideal state in which there was no private property, all people worked and had the opportunity to engage with scientific inquiry and arts. The system of education and upbringing in an ideal city is exclusively social and the same for all citizens. It is organized in such a way that all children develop their strengths and abilities. Campanella paid great attention to intellectual education, which should be combined with physical, moral, and aesthetic education and with the preparation of children for a particular profession. For the thinker, the comprehensive development of a child directly related to work was the main purpose of education.

\section{CONCLUSIONS}

The complex processes in the spiritual life of medieval Europe contributed to the emergence of the humanistic tradition of the Renaissance and the religious reform movements (Lutheranism, Calvinism, Anglicanism). In general, both the Renaissance and the Reformation cultures opposed the ideology and social institutions that prevailed at the time, but in the spirit they were opposites. If humanism preached the idea of the harmonious development of an individual who could improve all spheres of society [5], then the ideology of the Reformation was based on the idea of a community that subjugated the individual. At the end of the 16th century, the humanistic worldview was almost completely pushed to the background by the ideology of the Reformation and Counter-Reformation. Its revival took place only in the era of the Enlightenment. 


\section{REFERENCES}

1. Boecio, A. M. T. S., Tester, S. J., Rand, E. K., \& Stewart, H. F. (1978). The theological tractates; The consolation of philosophy. Cambridge, Massachusetts: Harvard University Press.

2. Campanella, T. (2014). The city of the sun: A poetical dialogue between a Grandmaster of the Knights Hospitallera and a Genoes Sea-Captain. CreateSpace Independent Publishing Platform.

3. Clement. (1968). The Writings of Clement of Alexandria. Edinburgh: T. \& T. Clark.

4. Danylova, T. V. (2016). The desire for recognition in the context of Francis Fukuyama's universal history. Anthropological Measurements of Philosophical Research, 10, 69-77. doi: 10.15802/ampr.v0i10.87303

5. Danylova, T. V. (2017). Eastern mysticism and timothy leary: human beyond the conventional reality. Anthropological Measurements of Philosophical Research, 11, 135-142. doi: 10.15802/ampr.v0i11.105498

6. Danylova, T. V., \& Salata, G. V. (2018). The Ecological Imperative and Human Nature: A New Perspective on Ecological Education. Interdisciplinary Studies of Complex Systems, 12, 17-24.

7. Gutek, G. L. (1995). A History of the Western Educational Experience (2nd ed.). Long Grove: Waveland Press.

8. Montaigne de, M. (1993). The Complete Essays. Garden City: Doubleday.

9. More, T. (2007). Utopia. Tark Classic Fiction.

10. Origen. (2016). The Complete Works of Origen: Cross-Linked to the Bible. Ontario: n. d.

11. Petrarch, \& Hainsworth, P. (2010). The Essential Petrarch. Indianapolis: Hackett Publishing Company, Inc

12. Phau, D. (1995). Erasmus of Rotterdam: The Educator's Educator. Retrieved from https://archive.schillerinstitute.com/fid_91-96/952_erasmus.html

13. Pieper, J. (2019). Scholasticism. Retrieved from https://www.britannica.com/topic/Scholasticism

14. Saint Augustine. (1958). The City of God. Image: Abridged Edition.

15. Thomas, Aquinas Saint, \& O'Brien, T. C. (2006). Summa theologiae. Cambridge: Cambridge University Press. 